\title{
COMPARATIVE STANDARDIZATION OF MARKETED FORMULATIONS OF FERMENTED BIOMEDICINE - ARJUNARISTHA
}

\author{
Dheeraj S. Randive ${ }^{1 *}$, Somnath D. Bhinge ${ }^{1}$, Ganesh H. Wadkar ${ }^{1}$, Sadik F. Sayyad ${ }^{2}$, \\ Mangesh A. Bhutkar ${ }^{1}$
}

\begin{abstract}
1Department of Pharmaceutics Rajarambapu College of Pharmacy, Kasegaon, Tal. Walwa, Dist. Sangli, MS, India 415404 2Department of Pharmaceutics Amrutvahini College of Pharmacy, Sangamner, Tal. Sangamner, Ahmednagar, MS, India
\end{abstract}

Submitted: 03-10-2015 Revised: 28-10-2016 Accepted: $10-11-2016$

*Corresponding author Dheeraj S. Randive

Email: randivedheeraj@gmail.com

\begin{abstract}
Ayurvedic formulations have proved to be effective in the prevention and treatment of many life-threatening diseases. Asavas and Arishtas have been used as medicine for over 3000 years as appetizer and stimulant. in the present study 6 different marketed brands (two having different batches) of Arjunarishta were thoroughly evaluated for their organoleptic characteristics and physicochemical parameters, to establish a routine procedure for standardization of these Ayurvedic formulations. The organoleptic tests performed include colour, odour and taste whereas the physicochemical parameters evaluated were $\mathrm{pH}$, refractive index, specific gravity, viscosity, density, surface tension, water-soluble extractive, alcohol-soluble extractive, acid value, alcohol content, by distillation and dichromate oxidation method, total solid content, total phenol content. In present communication, a TLC method was developed for the evaluation of Arjunarishta by quantitative estimation of major compound gallic acid and ellagic acid. The Baidyanath Arishta has maximum $(11.2 \% \mathrm{v} / \mathrm{v})$ and Dhutapeshwar Arishta has minimum (5.2\% v/v) self generated alcohol. This is important evaluation parameter for Asava and Arishta. From the above study we conclude that variation in the different parameters of evaluation of marketed formulation, by utilizing modern technique and tools we can prepare and standardize these formulations to minimize these gaps, which will improve global use of ayurvedic formulations.
\end{abstract}

Keywords: Ayurveda, Arjunarishta, Marketed formulation, Thin layer chromatography.

\section{INTRODUCTION}

Alternative systems of medicine such as Ayurveda, Siddha and Unani systems have the potential of health care for ever-increasing population of India. They represent formal and organized of all traditional medical systems required for the product to be manufactured for sale. Ayurveda, the most ancient system of medicine plays an important role for prevention and cure of diseases and for achieving and maintaining excellent health. (US Department of Health and Human Services, 2009). Advancement in Ayurvedic medicine has been revolution-raised from the screening of phytochemicals, pharmacological activities to elucidating their mechanisms and sites of action. The preparations are prescribed in Ayurveda to strengthen general host resistance (Thatte et al., 1986)
Aasava or Aristas are fermented biomedicine derived from medicinal plants. Aasavas are usually prepared by fermenting expressed juice ('swarasa'), whereas 'Arishtas' are prepared from fermentation of decoction.(Randive et al., 2016; Savarikar and Ravishankar, 2010) They have been used as medicines for over 3000 years to treat various disorders and are also taken as appetizers and stimulants. Due to their medicinal value, sweet taste, and easy availability people are prone to consume higher doses of these drugs for longer periods. The manufacture and sale of Arishta and Asava occupies an important place in the ayurvedic pharmaceutical industry. (Weerasooriya et al., 2010) Arjunarishta (ParthadyArishta) is one of the ancient liquid oral formulations prescribed in Ayurveda for cardiovascular disorders. It nourishes and 
strengthens heart muscle and promotes cardiac functioning by regulating blood pressure and cholesterol. (Lal et al., 2009)

In order to assure a consistent and acceptable quality herbal product, care should be taken right from the identification and authentication of herbal raw materials to the verification process of final product. (Mosihuzzaman and Chaudhari, 2008)

Evaluation of Ayurvedic medicines prescribed by utilizing modern scientific tools and techniques reveals the fact that they are amazingly relevant even today and have the capabilities to take global care of the disease. (Tiwari, 2005)

Marketed formulations of Aristha should be evaluated for physical and chemical parameters like viscosity, density, refractive index, acid value, alcohol content (Indian pharmacopoeia, 2007) to maintain the quality, safety and efficacy of product.

In the present study we tried to implement current evidence based knowledge for modernization of traditional Arishta formulation, thus, we have undertaken the comparative standardization of marketed Arjunaristha formulations of fermented biomedicine.

\section{MATERIALS AND METHODS Procurement of formulation}

Total 8 marketed formulation of Arjunarishta of 6 different brands with 2 having different batches were procured form local market of Sangamner, Ahmednagar.

\section{Evaluation of marketed formulations of Arjunarishta Physicochemical evaluation}

Organoleptic characteristics, colour, odour, taste, of marketed formulations of Arjunarishta were carried out as per the procedure given in Indian Pharmacopoeia 1996 (Table I). Physicochemical Evaluation viz. pH, Viscosity, Refractive Index and Acid value were determined as per the procedure given in Indian Pharmacopoeia (Indian pharmacopoeia, 2007). Determination of density, density of all the samples was determined by using pycknometer. (Subrahmanyam and Vasantharju, 1997). Determination of surface tension, provides the information regarding the structure of molecule. Surface tensions of all the samples were determined by using Stalagnometer. Determination of water and alcohol soluble extractive, water soluble extractive and alcohol soluble extractive were determined as per the method described in (Indian Pharmacopoeia, 2007)

\section{Identification test for alcohol production}

Sample $(5 \mathrm{~mL})$ was taken to this $1 \mathrm{~mL}$ $0.5 \% \mathrm{w} / \mathrm{v}$ solution of $1 \mathrm{M}$ sodium hydroxide was added followed by slow addition of $2 \mathrm{~mL}$ of iodine solution added the odour of iodoform and yellow precipitate indicates presence of alcohol (Indian Pharmacopoeia, 2007)

\section{Quantitative determination of alcohol content by distillation method}

Sample (25mL) was transferred to the distillation flask and its temperature was noted. It was diluted with $150 \mathrm{~mL}$ of water and distilled. The distillated sample, about $2 \mathrm{~mL}$ less than the total volume, was collected. Water was added to make up exactly same volume of original test liquid and adjusted to temperature noted before. Specific gravity of this liquid was determined and alcohol content was analyzed using relative density table given in USP/NF (United States pharmacopoeia, 2009)

\section{Alcohol content determination}

Approximately $10 \mathrm{~mL}$ of formulation was taken and $15 \mathrm{~mL}$ water was added and distilled to obtained $20 \mathrm{~mL}$ of distillate. Eventually, $5 \mathrm{~mL}$ of water was added. Approximatelly, $0.5 \mathrm{~mL}$ volume was taken and $2 \mathrm{~mL}$ water as well as $2.5 \mathrm{~mL}$ potassium dichromate solution was added. Absorbance was measured at 590nm. Calibration curve of alcohol determination was plotted similarly by using known concentration of ethanol as $(1 \%$ to $8 \% \mathrm{v} / \mathrm{v})$ From the equation of calibration curve, alcohol content of all formulation were determined. (Hyun-BS et al, 2009)

\section{Total solid content}

A $25 \mathrm{~mL}$ of a formulation was taken in evaporated dish which was previously weighed and allowed to evaporate so that only solid content remains in the dish and rest of the fluid would evaporate. The sample was then weighed and the solid content of formulation calculated (Ayurvedic Pharmacopoeia of India, 2001). 
Dheeraj S. Randive

Table I. Organoleptic characteristics of marketed formulations.

\begin{tabular}{lccc}
\hline \multicolumn{1}{c}{ Particulars } & Colour & Odour & Taste \\
\hline Baidyanath 1 & Dark brown & Alcoholic & Sweet \\
Baidyanath 2 & Dark brown & Alcoholic & Sweet \\
Dabur & Faint brown & Alcoholic & Sweet \\
Sandu & Brown & Alcoholic & Sweet \\
Dhootapapeshwar 1 & Dark brown & Alcoholic & Sweet \\
Dhootapapeshwar 2 & Dark brown & Alcoholic & Sweet \\
Aushadhibhavan & Dark brown & Alcoholic & Sweet \\
Arkashalasatara & Brown & Alcoholic & Sweet \\
\hline
\end{tabular}

Table II. $\mathrm{p}^{\mathrm{H}}$ Change of marketed formulation.

\begin{tabular}{ccccccccc}
\hline Days & $\begin{array}{c}\text { Baidyanath } \\
\mathbf{( 1 )}\end{array}$ & $\begin{array}{c}\text { Baidyanath } \\
\mathbf{( 2 )}\end{array}$ & Dabur & Sandu & $\begin{array}{c}\text { Dhootapa } \\
\text { pesh war (1) }\end{array}$ & $\begin{array}{c}\text { Dhootapa } \\
\text { pesh war (2) }\end{array}$ & $\begin{array}{c}\text { Aushadhi } \\
\text { bhavan }\end{array}$ & $\begin{array}{c}\text { Arkashala } \\
\text { satara }\end{array}$ \\
\hline $\mathbf{1}$ & 3.93 & 3.71 & 4.01 & 4.26 & 5.23 & 5.10 & 3.85 & 3.45 \\
$\mathbf{2}$ & 3.79 & 3.62 & 3.95 & 4.14 & 5.13 & 5.10 & 3.76 & 3.56 \\
$\mathbf{3}$ & 4.04 & 3.76 & 4.06 & 4.23 & 5.20 & 5.18 & 3.88 & 3.55 \\
$\mathbf{4}$ & 4.02 & 3.74 & 4.05 & 4.22 & 5.19 & 5.18 & 3.85 & 3.54 \\
$\mathbf{5}$ & 4.01 & 3.74 & 4.04 & 4.22 & 5.19 & 5.17 & 3.84 & 3.54 \\
$\mathbf{6}$ & 4.00 & 3.72 & 4.03 & 4.21 & 5.18 & 5.16 & 3.83 & 3.54 \\
$\mathbf{7}$ & 4.00 & 3.70 & 4.01 & 4.18 & 5.18 & 5.16 & 3.82 & 3.50 \\
$\mathbf{8}$ & 3.98 & 3.68 & 4.00 & 4.17 & 5.17 & 5.16 & 3.81 & 3.49 \\
$\mathbf{9}$ & 4.02 & 3.73 & 4.05 & 4.21 & 5.18 & 5.18 & 3.84 & 3.55 \\
$\mathbf{1 0}$ & 4.00 & 3.68 & 4.00 & 4.21 & 5.18 & 5.16 & 3.81 & 3.49 \\
$\mathbf{1 1}$ & 3.99 & 3.69 & 4.02 & 4.20 & 5.17 & 5.15 & 3.80 & 3.51 \\
$\mathbf{1 2}$ & 3.98 & 3.69 & 4.01 & 4.20 & 5.16 & 5.15 & 3.81 & 3.51 \\
$\mathbf{1 3}$ & 3.99 & 3.68. & 4.01 & 4.20 & 5.16 & 5.14 & 3.81 & 3.52 \\
$\mathbf{1 4}$ & 3.99 & 3.69 & 4.02 & 4.19 & 5.15 & 5.14 & 3.81 & 3.53 \\
\hline
\end{tabular}

Quantitative determination of phenol content

Absorbance of standard tannic acid solutions are recorded on UV-visible spectrophotometer (Shimadzu-1800) at 750nm and standard curve is plotted. The phenolic content is expressed as tannic acid equivalent, Sample of Arjunarishta was processed for determination of total phenolic content, as per the Folin-ciocalteau method (Rajalakshamy and Sindu, 2011).

\section{Thin layer chromatography}

TLC- method was developed using Precoated TLC Plate (Silica gel $60 \mathrm{~F}_{254}$ ) for the standardization of Arjunarishta. Different solvents Tolune, Benzene, Ethyle Acetate, Acetic Acid, Formic Acid, Methanol, Water, Hydrochloric Acid were screened for development of mobile phase. The Visualizing agent such as UV chamber, Iodine, Folins reagent, Methanolic Ferric chloride and Anisaldehyde $\mathrm{H}_{2} \mathrm{SO}_{4}$ were used to identify the spots. Solvent system selected which gives maximum number of spots. The optimized mobile was Tolune:ethyleacetate:formic acid (5:5:1). Gallic acid and Ellagic acid were used as Reference Standard.

\section{RESULTS AND DISCUSSION}

Various approaches have been followed to encourage standardization of Arjunarishta formulations. Sowe have taken Baidyanath, Dabur, Sandu, Dhootapapeshwar, Aushadhib-havan and Arkashalasatara The selected formulations were subjected to various evaluations studies done such as; $\mathrm{pH}$, refractive index, density, specific gravity, surface tension, water-soluble extractive, alcohol-soluble extractive, viscosity, acid value, alcohol content by distillation, 
Table III. Results of evaluations of physicochemical parameter of marked formulations.

\begin{tabular}{|c|c|c|c|c|c|c|c|c|}
\hline Particulars & $\begin{array}{l}\text { Baidya } \\
\text { nath } 1\end{array}$ & $\begin{array}{l}\text { Baidya } \\
\text { nath } 2\end{array}$ & Dabur & Sandu & $\begin{array}{l}\text { Dhootapa } \\
\text { peshwar } 1\end{array}$ & $\begin{array}{l}\text { Dhootapa } \\
\text { peshwar } 2\end{array}$ & $\begin{array}{c}\text { Aushadhi } \\
\text { bhavan }\end{array}$ & $\begin{array}{l}\text { Arkashala } \\
\text { Satara }\end{array}$ \\
\hline \multirow{2}{*}{$\mathrm{pH}$} & $3.98 \pm$ & $3.70 \pm$ & $4.01 \pm$ & $4.20 \pm$ & $5.17 \pm$ & $5.15 \pm$ & $3.82 \pm$ & $3.52 \pm$ \\
\hline & 0.06 & 0.03 & 0.03 & 0.03 & 0.02 & 0.02 & 0.03 & 0.03 \\
\hline Refractive index & 1.390 & 1.386 & 1.386 & 1.340 & 1.386 & 1.387 & 1.388 & 1.385 \\
\hline Density (gm/cm3) & 1.140 & 1.145 & 1.077 & 1.119 & 1.132 & 1.129 & 1.115 & 1.117 \\
\hline Specific gravity & 1.072 & 1.041 & 1.071 & 1.090 & 1.070 & 1.070 & 1.080 & 1.090 \\
\hline $\begin{array}{l}\text { Surface tension } \\
(\text { dynes } / \mathrm{cm})\end{array}$ & 58.35 & 60.55 & 70.20 & 65.89 & 70.60 & 71.95 & 80.50 & 75.75 \\
\hline $\begin{array}{l}\text { Water-soluble } \\
\text { extractive }(\% \mathrm{w} / \mathrm{w})\end{array}$ & 11.5 & 10.9 & 11.8 & 9.9 & 10.8 & 11.1 & 11.4 & 10.1 \\
\hline $\begin{array}{l}\text { Alcohol-soluble } \\
\text { extractive }(\% \mathrm{w} / \mathrm{w})\end{array}$ & 10.9 & 10.6 & 11.2 & 9.8 & 9.9 & 10.8 & 10.9 & 10.6 \\
\hline Viscosity (cps) & $\begin{array}{c}2.04 \pm \\
0.01\end{array}$ & $\begin{array}{c}2.03 \pm \\
0.01\end{array}$ & $\begin{array}{c}1.44 \pm \\
0.12\end{array}$ & $\begin{array}{c}2.03 \pm \\
0.01\end{array}$ & $\begin{array}{c}2.93 \pm \\
0.04\end{array}$ & $\begin{array}{c}2.49 \pm \\
0.04\end{array}$ & $\begin{array}{c}2.36 \pm \\
0.13\end{array}$ & $\begin{array}{c}2.50 \pm \\
0.10\end{array}$ \\
\hline Acid value & $\begin{array}{c}0.09 \pm \\
0.01\end{array}$ & $\begin{array}{c}0.09 \pm \\
0.01\end{array}$ & $\begin{array}{c}0.08 \pm \\
0.02\end{array}$ & $\begin{array}{c}0.08 \pm \\
0.01\end{array}$ & $\begin{array}{c}0.09 \pm \\
0.03\end{array}$ & $\begin{array}{c}0.09 \pm \\
0.01\end{array}$ & $\begin{array}{c}0.09 \pm \\
0.04\end{array}$ & $\begin{array}{c}0.09 \pm \\
0.03\end{array}$ \\
\hline $\begin{array}{c}\text { Alcohol content } \\
(\% \mathrm{v} / \mathrm{v}) \text { by distillation }\end{array}$ & 11.2 & 8.0 & 8.0 & 8.0 & 5.2 & 5.6 & 10.8 & 8.0 \\
\hline $\begin{array}{c}\text { Alcohol content } \\
(\% \mathrm{v} / \mathrm{v}) \text { by dichromate }\end{array}$ & 9.65 & 10.30 & 6.17 & 5.51 & 6.11 & 5.22 & 7.50 & 8.12 \\
\hline $\begin{array}{c}\text { Total solid content } \\
(\% \mathrm{w} / \mathrm{v})\end{array}$ & $\begin{array}{c}6.36 \pm \\
0.04\end{array}$ & $\begin{array}{c}6.71 \pm \\
0.23\end{array}$ & $\begin{array}{c}6.74 \pm \\
0.13\end{array}$ & $\begin{array}{c}9.32 \pm \\
0.16\end{array}$ & $\begin{array}{c}10.50 \pm \\
0.38\end{array}$ & $\begin{array}{c}10.90 \pm \\
0.04\end{array}$ & $\begin{array}{c}7.72 \pm \\
0.11\end{array}$ & $\begin{array}{c}6.37 \pm \\
0.21\end{array}$ \\
\hline $\begin{array}{c}\text { Total phenol content } \\
(\% \mathrm{w} / \mathrm{v})\end{array}$ & 6.7 & 7.5 & 3.9 & 2.9 & 6.7 & 4.8 & 6.3 & 7.6 \\
\hline
\end{tabular}

alcohol content by dichromate, total solid content, total phenol content and thin layer chromatography. These are as follows.

\section{Measurement of pH}

The $\mathrm{pH}$ of formulations was analyzed for consecutive 14 days (Table II) to evaluate acidity of formulation and effect of environmental conditions on $\mathrm{pH}$. All formulations were found acidic and there is no much more change in $\mathrm{pH}$ after opening container and storing it for few days. Among the screened formulation Dhootapeshwar shows maximum $\mathrm{pH}=5.152$ and Arkashala Satara shows $\mathrm{pH}=3.52$. Generally formulations having less alcohol content have higher $\mathrm{pH}$ (Table III).

\section{Refractive index}

Refractive index of water and absolute alcohol were 1.333 and 1.361, respectively. Marketed formulations showed refractive index 1.340 (Sandu) to 1.390 (Baidyanath) (Table III) indicating the presence of plant drug changes the refractive index of liquid formulation.

\section{Viscosity}

All evaluated marketed formulations have viscosity $1.436 \mathrm{cps}$ to $2.926 \mathrm{cps}$ (Table III) among these Arishta of Dabur showed minimum whereas Arishta of Dhootapeshwar showed maximum viscosity.

\section{Alcohol content}

It was determined by distillation method and dichromate technique. Dichromate method was more reliable for alcohol content determination as distillation method shows fluctuations in repeated results due to minor errors. Among the marketed formulation, Baidyanath Arishta has maximum $(11.2 \% \mathrm{v} / \mathrm{v})$ and Dhutapeshwar Arishta has minimum $(5.2 \% \mathrm{v} / \mathrm{v})$ alcohol (Table III). As per Ayurvedic Pharmacopoeia of India the limit for Arjusnarishta alcohol content should be in the range 6 to $12 \% \mathrm{v} / \mathrm{v}$. Arishta of Dhutapeshwar not complies with this limit.

\section{Total solid content}

Total solid content have moderate impact over viscosity. Increase in solid content increases viscosity. All evaluated marketed 
Dheeraj S. Randive

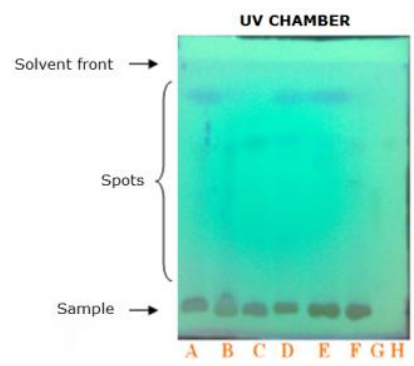

Figure 1: In UV Chamber TLC of marketed formulations and marker compounds ADhootpapeshwar, B-Dabur, C-Arkashala Satara, D-Aushadhi bhavan,ESandu,FBaidyanath, GEllagic acid, H-Gallic acid

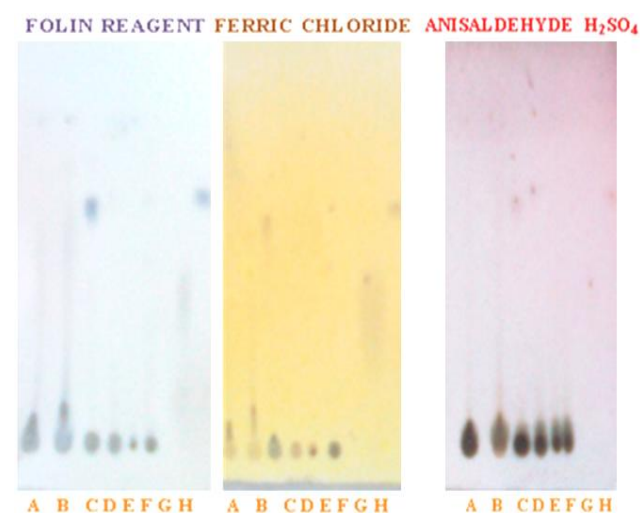

Figure 2. Thin layer chromatography marketed formulations. A-Dhootpapeshwar, B-Dabur, CArkashala Satara, D-Aushadhi bhavan,ESandu,FBaidyanath, G-Ellagic acid, H-Gallic acid

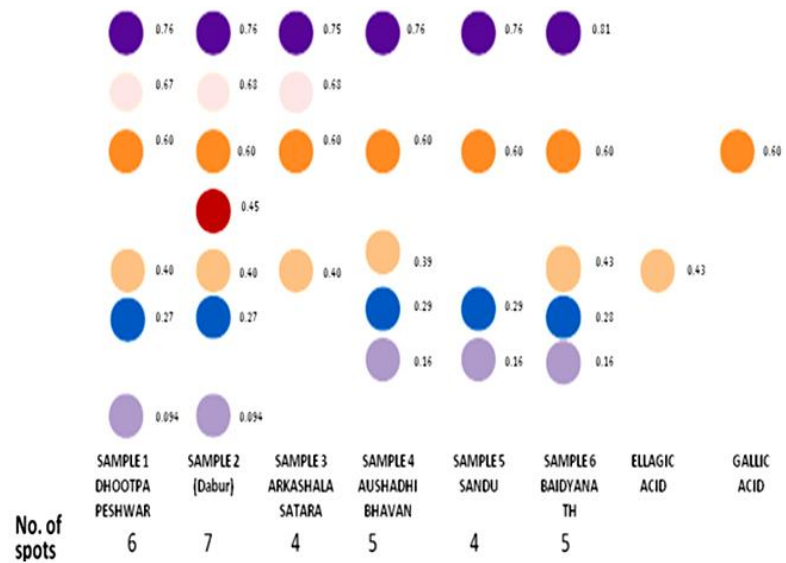

Figure 3. Marketed sample and marker compounds (Ellagic acid and Gallic acid) TLC profiling

formulations have total solid content of 10.88 to $6.365 \% \mathrm{w} / \mathrm{v}$ among these Arishta Dhootapeshwar shows maximum whereas Baidyanath shows minimum total solid content (Table III).

\section{Total phenol content}

Total phenol content has impact over $\mathrm{pH}$ of formulation. $\mathrm{pH}$ and total phenol content inversely related. All evaluated marketed formulations have total phenol 
content maximum of $7.6 \% \mathrm{w} / \mathrm{v}$ and minimum of $3.9 \% \mathrm{w} / \mathrm{v}$ (Table III).

\section{Thin layer chromatography}

From the TLC profiling of marketed formulation (Figure 3) it was found that Dabur having maximum 7 number of spots and Sandu having minimum 4 number of spots (Figure 1 and 2) that indicating there is variation in content of the different marketed formulations. Even different batches of same brand also showed variations in TLC profiling. This create problem for quality control of formulations and also affects its efficacy.

\section{CONCLUSION}

Despite of existence and continued extensive use of Ayurvedic medicine over many centuries, traditional medicine has not been officially recognized in most countries. From the above study we conclude that variation in the different parameters of evaluation of marketed formulation was may be due to some reasons that sources of herbs or plant, collection period, method of preparation affected the quality, safety and efficacy of ayurvedic formulation. There was also slight variation in the different batches of same brand so lacking reproducibility of result. By utilizing modern technique and tools we can prepare and standardize these formulations to minimize these gaps, which will improve global use of ayurvedic formulations.

\section{REFERENCES}

Hyun-BS., Hyun-J K., et al. 2009. Measurement of ethanol concentration using solvent extraction and dichromate oxidation and its application to bioethanol production process. J. Ind. Microbiol. Biotech., 36: 285292

Indian Pharmacopoeia, 1996. Vol 2: Ministry of Health and Family Welfare, Govt. of India, Indian Pharmacopoeia Commission, Ghariabad, pp. A-86-89, A-53.

Indian Pharmacopoeia, 2007. Vol 1 \& 2: Ministry of Health and Family Welfare, Govt. of India, Indian Pharmacopoeia Com-mission, Ghariabad, pp.141, $163,165,1101$.
Lal UR., Tripathi SM., Jachak SM., Bhutani KK., Sing IP., 2009. HPLC Analysis and Standardization of ArjunArishta - An Ayurvedic Cardioprotective Formulation. Scientica Pharmaceutica; 77: 605-616.

Mosihuzzaman M., Chaudhari I., 2008. Protocol on Safety, Efficacy, Standardization and documentation of herbal drug. Pure Appl. Chem., 80 (10): 2195

Rajalakshamy MR., Sindu A., 2011. Preliminary phytochemical screening and antioxidant activity of an ayurvedic formulation: BalArishtam. Int. J. Res. Ayur. Pharm., 2 (6): 1645-1647.

Randive DS., Sayyad SF., Bhinge SD., Bhutkar MA., 2016. Preparation of arjunāristausing microbes isolated from woodfordia fruticosa flowers (dhayati). Anc. Sci. Life, 36 (1): 42-47.

Savarikar SS., Ravishankar B., 2010. Bhaishajya kalpanaa the ayurvedic pharmaceuticsan rerview. Afr. J. Trad. Compl. Alternative med. 7 (3): $174-184$.

Subrahmanyam C.V.S., Vasantharju S.G., 1997. Practical book of Physical Pharmacy, edition 1st.Vallabh Prakashan.8-15, 56-63.

Thatte UM, Sharadini A. Dahanukar, 1986. Ayurveda and contemporary scientific thought, Trends in pharmacological science, pp. 247-251.

The Ayurvedic Pharmacopoeia of India, 2001. Vol 2 (2): Ministry of health and family welfare, Govt. of India, Department of Indian Systems of Medicine and Homeopathy, Controller of Publications, New Delhi, pp. 47,221.

Tiwari AK., 2005. Wisdom of ayurveda in perceiving diabetes: enigma of therapeutic recognition. Current Science., 88 (7): 10431051

United states pharmacopoeia and National formulary 2009. vol 1: The official compendia of Standards, pp. 224- 225, 954.

US Department of Health and Human services, 2009. National center for complementtary and alternative medicine. pp. 3-4.

Weerasooriya WMB., Liyange JA., Pandya SS., 2006. Quantitative parameters of different brands of asava and Arishta used in ayurvedic medicine: an assessment. Ind. J. Pharmacol., 38(5): 365. 